Artikel

\title{
Analysis and Design Information System using CPM (Critical Path Method) Method the web-based at PT.Pakarti Tirtoagung
}

\author{
Edy $^{1}$, Bella Liantono ${ }^{2}$ \\ ${ }^{1,2}$ Information System, Buddhi Dharma University, Banten, Indonesia
}

\begin{tabular}{l}
\hline SUBMISSION TRACK \\
\hline Received 20 December 2018; \\
Revised 12 January 2019; \\
Accepted 10 February 2019; \\
Available online 20 February 2019 \\
KEYWORD \\
\hline Information Systems, Project Estimates, Project \\
Managers, CPM (Critical Path Method) \\
KORESPONDENSI \\
\hline
\end{tabular}

E-mail: bellaliantono68@gmail.com

\begin{tabular}{l} 
ABSTRACT \\
\hline Project planning has several stages or project activity plans that \\
can result in the running of a project more optimally to the project \\
estimation that can help the planning manager or project manager \\
work together in preparing project implementation at PT. Pakarti \\
Tirtoagung. PT. Pakarti Tirtoagung is a business that will produce \\
an intangible product (service) / service activity for construction \\
and oil services that will be used for the needs of other companies. \\
Problems at PT. Pakarti Tirtoagung in processing project data \\
using the MS system. Excel which results in data redundancy so it \\
must check data - data and must be input again. This results in \\
data redundancy and lack of data consistency so the presentation \\
of project manager information is less accurate. Then this research \\
uses CPM (Critical Path Method) method to determine the level of \\
project progress in order to optimize project duration, possibility \\
of accelerating time of project implementation and make it easier \\
as admin by supporting project estimation activities, making it \\
easier to manage planning of project activities and preparing a \\
project scheduling. The design is implemented using PHP and \\
MySQL database servers.
\end{tabular}

plan of activity, scheduling, managing in project activities that make a project in the project so that it can have a very important role in planning and scheduling a project of a company that concerns the management of data, costs, time that has been determined so that it can plan projects that estimate costs and time or have delays in completion the project. Therefore a company that has problems in elaborating data related to project estimates cannot plan existing project data PT. Pakarti Tirtoagung. PT. Pakarti Tirtoagung is a business that will produce an intangible product (service) / service activities for construction services that will be used for the needs of other companies. 
Based on the company's problems, PT. Pakarti Tirtoagung in planning, scheduling, managing in project activities that make a project estimation data collection that is payment transaction, project, customer and transaction arrears in project implementation which makes a report to be given to managers in using Ms.Excel system stored in the folder - folder so that there are difficulties in finding data that requires an accurate data collection project planning will result in data redundancy (the same data / data repetition) to be implemented. So we need a system that aims to formulate plans to project scheduling (time schedule), manage and monitor project data estimates, facilitate the preparation of planning data recording presentation of project data that can predict / predict things clearly and completely. Data processing can be useful to further minimize the needs of human labor because the work that can already be done automatically with the use of computers will facilitate the use of the data project (project scheduling) and estimates the time period to be determined in order to know which project payment transactions have paid or not yet paid so that they can report on project data that generates reports in the form of tables. Based on these problems, we need a system to manage project estimation data to make it easier to operate the data so that all problems related to data management are resolved quickly and accurately. Therefore the researchers propose for the Analysis and Design of a Web-based Project Estimation Information System using the CPM (Critical Path Method) Method at PT. Pakarti Tirtoagung with PHP programming language uses MySQL database.

\section{THEORETICAL BASIS}

A. Definition Information Systems

According to Agusvianto (2017: 40) ${ }^{[1]}$ explains the notion "information system is a system organization that is meeting their needs in processing daily transactions support functions of organizational operations that are managerial with strategic activities of an organization is managerial with strategic activities of an organization and to be able to provide certain outside parties with reports that are needed.

\section{B. Definition of Analysis}

According to Mardi (2011: 124) ${ }^{[2]}$ "system analysis is a work process for testing information systems that already exist with their environment so obtained clues various possible improvements that can be done in improving the ability of the system.

\section{Definition of Design}

According to Al-Jufri (2011: 141) ${ }^{[3]}$ "system design is determination of the processes and data needed by new system. If the system is computer based, design can include equipment specifications that will be used. "

\section{Definition of Estimation}

According to Roger S.Press Man (2012: $832)^{[4]}$ "estimation is planning which requires making an initial commitment even though this" commitment "will likely prove wrong".

\section{E. Definition of Project}

According to Dr.Hafnidar A.Rani (2016: $6)^{[5]}$ "a project is an activity carried out with limited time and resources to achieve the final results determined. In achieving the final results, project activities are limited by 
budget, schedule and quality known as the three constraints ".

\section{FRAMEWORK}

In implementing a project a company must have predictions and plans in order to be able to prepare project will be carried out structured and appropriate. The company needs control in the project so that it can have a role in planning and scheduling a project that will be carried out and therefore researchers make a framework.

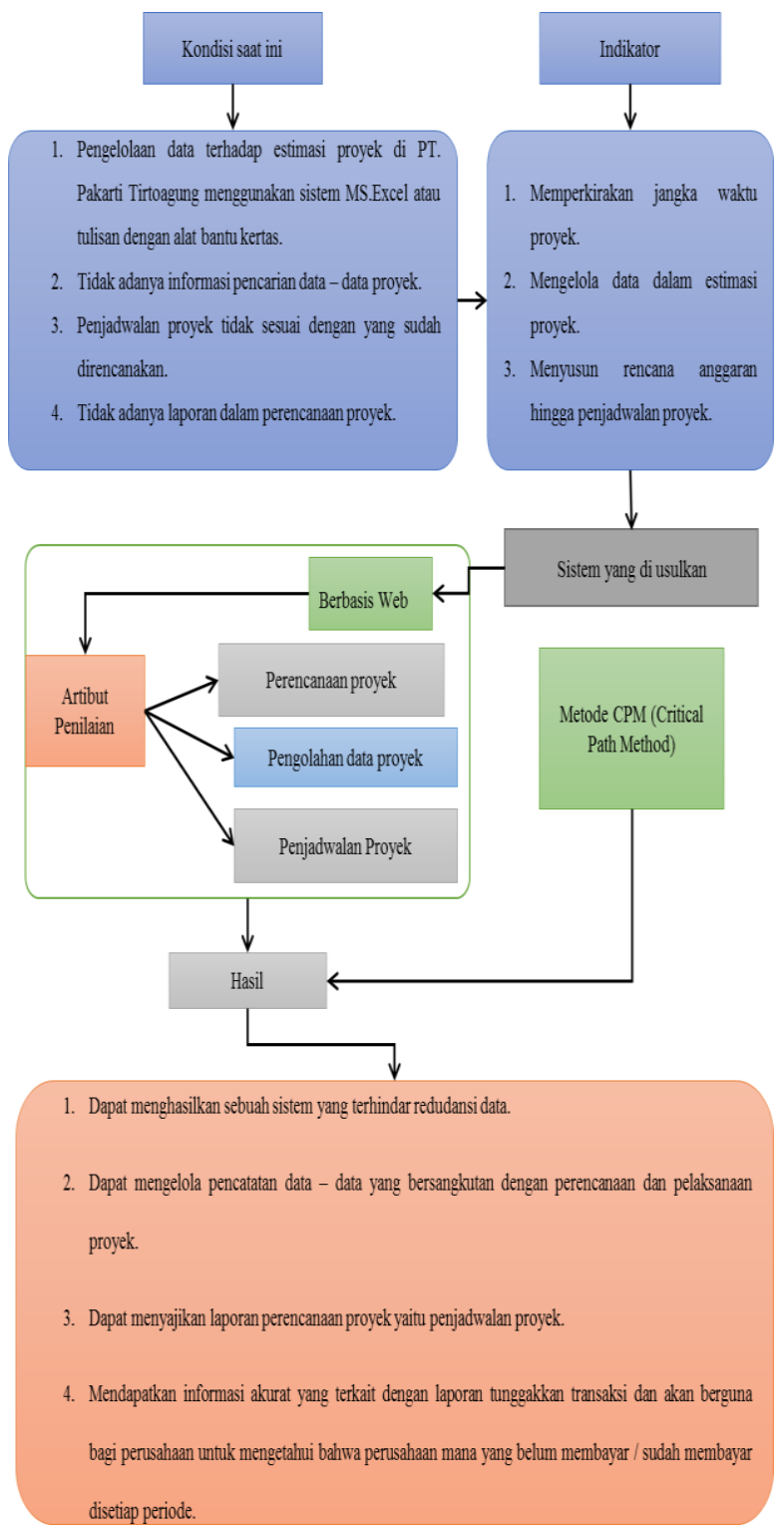

Image 1 Framework

\section{Method}

Waldi (2016: 181-182) ${ }^{[6]}$ define: "The CPM (Critical Path Method) method is known as existence of a critical path, which is a path has a series of activity components with longest total amount of time.

The benefits of knowing a critical path are as follows:

1. Postponement of work on the critical path causes all project work to be delayed for completion.

2.Project completion can be accelerated, if the work that is on the critical path can be accelerated.

3.Supervision or control can be controlled through the completion of a critical path that is right in its completion and the possibility of trade-offs (exchange of time with cost-efficient) and crash programs (completed with optimum time accelerated with increasing costs as well).

4.Time slack is available in work that does not go through critical trajectories.

Terms In CPM:

1. E (Earliest event occurence time): The fastest time an event occurs.

2. L (Latest event occurrence time): The slowest time that is still allowed for an event to occur.

3. ES (Earliest activity start time): The earliest start time of an activity. If the start time is stated in hours, then this time is the earliest hour the activity starts.

4. EF (Earliest activity finish time): The earliest Finish time for an activity. EF a previous activity $=\mathrm{ES}$ next activity.

5. LS (Latest activity start time): The slowest time an activity can be started without slowing down the project". 


\section{Result Calculation}

Karina Tika Aprilia (2015: 173) [7] The steps in determining CPM are as follows:

1. Divide the entire work into several occupational groups into several occupational groups which can be said to be of the same type.

2. Determine the duration of completion of each milestone's work.

3. Determine the relationship between the work groups.

4. Determine the critical path method for milestones based on the interrelationships.

5. Comparing the total duration of work with the time needed.

Ardian Riftha Dhuha \& Priyambadha (2017: 1368-1369) [8] "There are 2 stages of CPM calculation in determining the critical path, including:

1. Forward pass, starting from the Start (initial event) to Finish (terminal event) to calculate the fastest completion time of an activity (EF) and the fastest time to occur an activity (ES).

$E F(j)=E S(j)+\operatorname{Dur}(j)$

2. The countdown (backward pass), starting from Finish to Start to identify when the slowest occurrence of an activity (LF) and the slowest time of occurrence of an activity (LS).

$\operatorname{LS}(j)=\operatorname{LF}(j)-\operatorname{Dur}(j)$

3 . If the forward countdown and the countdown are completed, then the slack or total float (TF) slack value can be obtained is the time lapse or elasticity of the duration of an activity on the project, if the slack value of an activity is equal to 0 indicating the activity is the main activity (critical ), the main set of interconnected activities is called the critical path. Slack or total float can be calculated using the formula: " $\mathrm{TF}=\mathrm{LS}-\mathrm{ES}$

\section{Calculation of CPM Node Method}

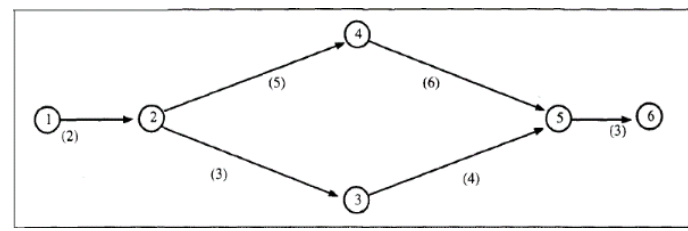

Image 2 Calculation of CPM Node Method

1. Advanced Count Table

Table 1 Advanced Count Table

\begin{tabular}{|c|c|c|c|c|c|}
\hline \multicolumn{3}{|c|}{ Activities } & \multirow{2}{*}{$\begin{array}{l}\text { Period } \\
\text { (D) }\end{array}$} & \multicolumn{2}{|c|}{ The Start } \\
\hline $\mathbf{i}$ & $\mathrm{j}$ & Name & & $\begin{array}{l}\text { Start } \\
\text { (ES) }\end{array}$ & $\begin{array}{l}\text { Finish } \\
(\mathrm{EF})\end{array}$ \\
\hline 1 & 2 & A & 2 & 0 & 2 \\
\hline 2 & 3 & B & 3 & 2 & 5 \\
\hline 2 & 4 & $\mathrm{C}$ & 5 & 2 & 7 \\
\hline 3 & 5 & D & 4 & 5 & 9 \\
\hline 4 & 5 & $E$ & 6 & 7 & 13 \\
\hline 5 & 6 & $\mathrm{~F}$ & 3 & 13 & 16 \\
\hline
\end{tabular}

Advanced calculations have several activities from 1-6 related to Figure 2 above.

Calculations start at $\mathrm{ES}=0$.

Calcultion $\mathrm{EF}=\mathrm{ES}+\mathrm{D}$

2. Reverse Count Table

Table 2 Reverse Count Table

\begin{tabular}{|c|c|c|c|c|c|}
\hline \multicolumn{3}{|c|}{ Activities } & \multirow{2}{*}{$\begin{array}{l}\text { Period } \\
\text { (D) }\end{array}$} & \multicolumn{2}{|c|}{ The start } \\
\hline $\mathbf{i}$ & $\mathrm{j}$ & Name & & $\begin{array}{l}\text { Start } \\
\text { (LS) }\end{array}$ & $\begin{array}{c}\text { Finish } \\
\text { (LF) }\end{array}$ \\
\hline 1 & 2 & A & 2 & 0 & 2 \\
\hline 2 & 3 & B & 3 & 6 & 5 \\
\hline 2 & 4 & $\mathrm{C}$ & 5 & 2 & 7 \\
\hline 3 & 5 & $\mathrm{D}$ & 4 & 9 & 9 \\
\hline 4 & 5 & $\mathrm{E}$ & 6 & 7 & 13 \\
\hline 5 & 6 & $\mathrm{~F}$ & 3 & 13 & 16 \\
\hline
\end{tabular}

The countdown has several activities 1-6 related to Figure 2.

Calculations start from $\mathrm{LS}=0$.

Then it will produce a day that can complete the project that is 16 days. 


\section{IV.DISCUSSION}

In the process of designing the proposed system using UML which can help the proposed system process as an admin at PT. Pakarti Tirtoagung:

\section{A. Use case Diagram Proposal}

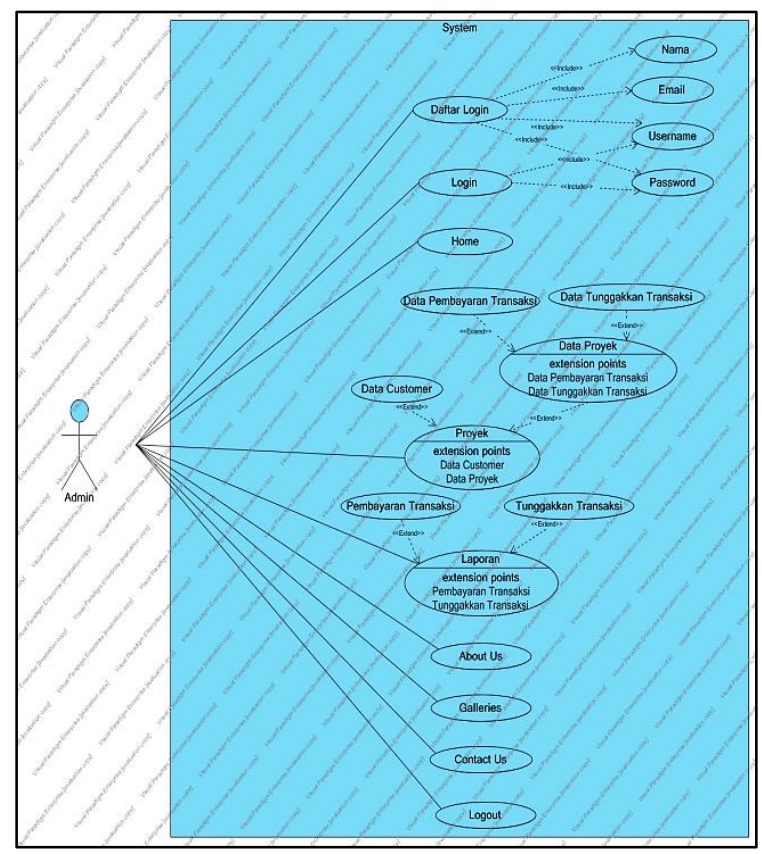

Image 3 Use Case Diagram

B. Hardware and software specifications

1. Hardware Specifications

a. Processor: Intel (R) Core (TM) i7-50000 U CPU @ $2.40 \mathrm{~Hz} 2.40 \mathrm{GHz}$ with Intel HD Graphics 4400

b. RAM: 4GB

c. Hard Disk Drive: 1 TB

d. Mouse

e. Keyboard

f. A printer

\section{Software Specifications}

a. Operating System: Genuine Windows 8.1 (64bit)

b. Notepad ++ c. Xampp Control Panel Application

C. Program Display

a. List Login

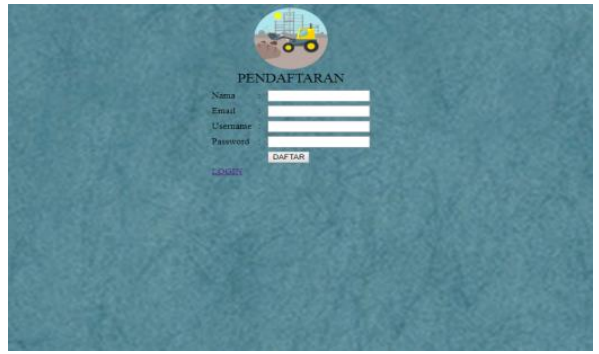

Image 4 List Login

Information: Login form form to register login which contains name, email, username and password.

b. Login

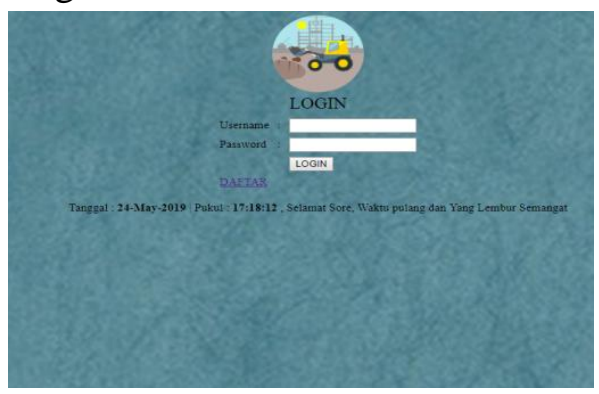

\section{Image 5 Login}

Note: The login form for the admin login that has been created.

c. Home

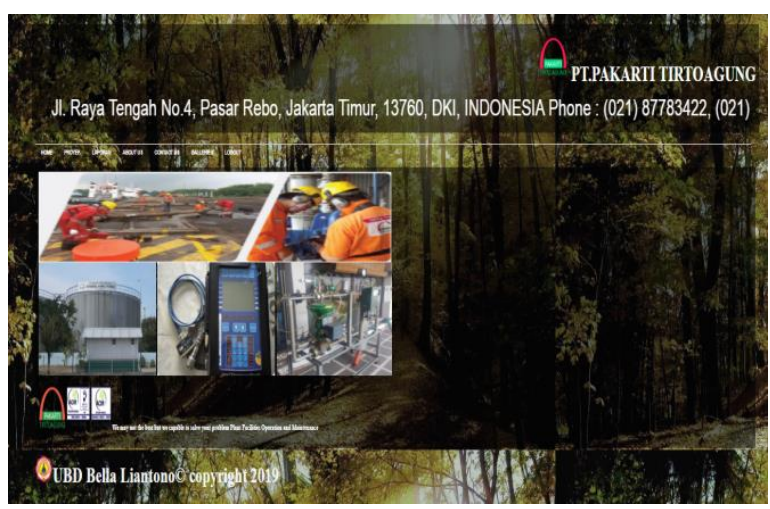

Gambar 6 Home

Note: Home is the main menu containing the project that is data proyek there is a sub menu of transaction payment 
data and transaction arrears data, customer data which is charging customers, projects to be planned, payment transactions that will pay for the project and arrears of transactions that will be in arrears for the company to know which ones have paid or not yet paid, report menu namely transaction payments and transaction arrears containing reports that will be printed or can be exported in excel or pdf, about us, contact us, galleries and logout.

\section{d. Report}

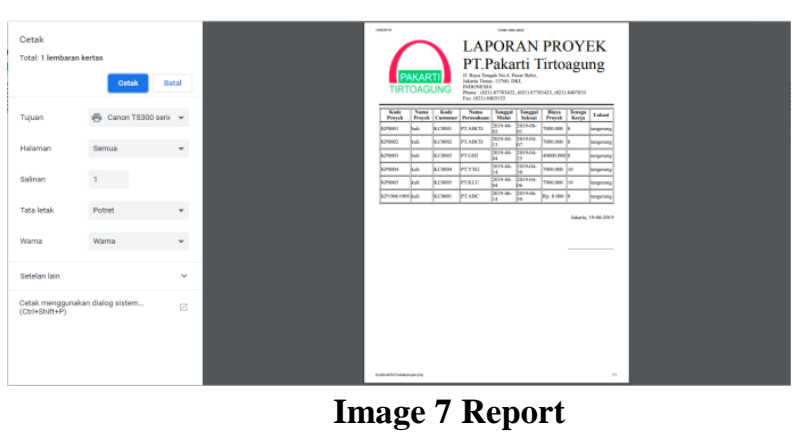

Note: Project data reports, transaction payment data, customer data and transaction arrears data to provide information contained in the system.

\section{Conclusion and Suggestion}

a. Conclusion

From results of research into the company PT.Pakarti Tirtoagung and conducted a questionnaire on the system that has been made, it can conclude that "Analysis and Design Information System using CPM (Critical Path Method) Method the webbased at PT.Pakarti Tirtoagung" has been completed built use PHP programming language that can be used by PT. Pakarti Tirtoagung where project data processing activities can be developed into a system that makes a project planning so that it can facilitate the operation for the smooth operation of production operations or save time that has been determined at the planned deadline.
Based on the results of the questionnaire that has been distributed and has been managed states $53 \%$ of this system can:

1. Support Project Estimation activities (60\% of respondents stated strongly agree and $30 \%$ agreed).

2. Make it easier for administrators to manage project planning activities $(60 \%$ of respondents agreed with the following statement).

3. Facilitate the user in estimating the duration of the project ( $70 \%$ of respondents agreed).

4. Arranging project scheduling and budget that will be issued in order to manage a project planning $(50 \%$ of respondents agree and $40 \%$ strongly agree with the following statement).

5. Transaction payment report and transaction arrears report $(60 \%$ of respondents agreed that the system is appropriate in displaying transaction reports and transaction arrears).

\section{b. Suggestion}

From the results of making Information Systems related to Project Estimation at PT. Pakarti Tirtoagung, giving advice so that the next stage of system development can be carried out including:

a. The system can print filters per project creation date in order to facilitate the search for project activity planning data.

b. Adding project transaction payments so that they can be calculated automatically and adding transaction payment income.

c. Sending emails to arrears of transactions by each customer that is in arrears on a project that has already been completed. 


\section{DAFTAR PUSTAKA}

[1] Agusvianto, H. (2017). Sistem Informasi Inventori Gudang Untuk Mengontrol Persediaan Barang pada Gudang Studi Kasus : PT. Alaisys Sidoarjo. Information Engineering and Educational Technology, 40, 70.

[2] Mardi. (2011). Sistem Informasi Akutansi (Vol. 1). Bogor: Ghalia Indonesia.

[3] Al-Jufri, H. (2011). Sistem Informasi Manajemen Pendidikan. Jakarta: PT.Smart Grafika.

[4] Roger S.Press Man, P. (2012). Rekayasa Perangkat Lunak (Vol. II). Yogyakarta: ANDI.

[5] Dr.Hafnidar A.Rani, S. (2016). Manajemen Proyek Konstruksi. Banda Aceh: Deepublish.

[6] Waldi, B. S. (2016, Desember). Analisa Penerapan Manajemen Waktu Dan Biaya Pada Proyek Pembangunan Hotel Bw Luxury Jambi. Jurnal Sains dan Teknologi Utama.

[7] Karina Tika Aprilia, I. F. (2015). Estimasi biaya dan penjadwalan proyek konstruksi CV.IStomu menggunakan metode CPM. Prosiding seminar informatika aplikatif polinema, 173.

[8] Ardian Riftha Dhuha, F. P., \& Priyambadha, B. (2017, November). Pengembangan Sistem Aplikasi Manajemen Proyek Berbasis Web (Studi Kasus: PT. Swadaya Graha). Jurnal Pengembangan Teknologi Informasi dan Ilmu Komputer, 1367-1375.

\section{RIWAYAT HIDUP}

Edy Graduated from the Informatics Engineering Study Program (S1) at Gunadarma University, 2004, STMIK ERESHA Informatics Engineering Program, 2012. Currently as a lecturer at the Faculty of Science and Technology, Buddhi Dharma University

Bella Liantono Graduated from the Information Systems Study Program (S1) in the Enterprise System, 2019. 